\title{
Sexual and gender minorities rights in Latin America and the Caribbean: a multi-country evaluation
}

Monica Malta ${ }^{1,2,3^{*}}$, Reynaldo Cardoso ${ }^{4}$, Luiz Montenegro ${ }^{5}$, Jaqueline Gomes de Jesus ${ }^{6}$, Michele Seixas ${ }^{7,8}$, Bruna Benevides ${ }^{9}$, Maria das Dores Silva ${ }^{10}$, Sara LeGrand ${ }^{11}$ and Kathryn Whetten ${ }^{11}$

\begin{abstract}
Background: Although the extent of legal inequities experienced by sexual and gender minorities (SGM) has declined during recent decades, this population still enjoys fewer legal protections and benefits than the nongender-variant, heterosexual population. Herein we analyze the current scenario of SGM rights in Latin America and the Caribbean (LAC).

Methods: Policy documents and governmental strategies addressing SGM rights were analyzed within a timeline framework by three major LAC sub-regions: the Caribbean, Mesoamerica and South America.

Results: Our search identified 88 eligible documents addressing the following categories: (1) legal protections towards same-sex couples (decriminalization of same-sex acts among consenting adults, legal recognition of samesex unions, same-sex marriage, adoption by same-sex couples), and (2) anti-discrimination laws (SGM allowed to serve openly in the military and anti-discrimination laws related to sexual orientation, gender identity and/or expression). The majority of Caribbean countries prohibit same-sex acts between consenting adults, while in Mesoamerica same-sex couples do not have equal marriage rights and are not allowed to adopt as a couple. In the Caribbean and Mesoamerica transgender people lack proper legal protection. Legislation to protect SGM rights in South America is the most inclusive and progressive in LAC. Several countries recognize same-sex marriage and the right of transgender people to legally change their name and gender. The majority of South American countries have some kind of anti-discrimination law, but no effective mechanisms to enforce these laws. In spite of those progresses, the LAC region registers the highest rate of violence and hate crimes against SGM in the world.

Conclusion: In the Caribbean and Mesoamerica the overall discriminatory legislation exacerbates violence against SGM within a social and cultural context of strong sexist, gender stereotypes and widespread violence. This scenario is driving hundreds of SGM to leave their home countries. In spite of progressive legislations, several South American countries are currently controlled either by highly conservative leaders (e.g. Brazil and Chile) or by repressive dictators (Venezuela). The near future of the LAC region is unknown, but if such trends continue, severe human rights problems, including setbacks in SGM legal protections, are likely.
\end{abstract}

\footnotetext{
* Correspondence: Monica.Malta@camh.ca

${ }^{1}$ Faculty of Medicine, Department of Psychiatry, University of Toronto,

Toronto, 33 Russell Street / Room RS 2035, Toronto, Ontario M5S 2S1,

Canada

${ }^{2}$ Institute for Mental Health Policy Research, Centre for Addiction and Mental

Health, Toronto, ON, Canada

Full list of author information is available at the end of the article
}

(c) The Author(s). 2019 Open Access This article is distributed under the terms of the Creative Commons Attribution 4.0 International License (http://creativecommons.org/licenses/by/4.0/), which permits unrestricted use, distribution, and reproduction in any medium, provided you give appropriate credit to the original author(s) and the source, provide a link to the Creative Commons license, and indicate if changes were made. The Creative Commons Public Domain Dedication waiver (http://creativecommons.org/publicdomain/zero/1.0/) applies to the data made available in this article, unless otherwise stated. 


\section{Background}

According to the Commission on Social Determinants of Health, from the World Health Organization, "social justice is a matter of life and death. It affects the way people live, their consequent chance of illness, and their risk of premature death" [1-3].

The lack of social justice and frequent social stressors (e.g. victimization and discrimination) affect health inequities frequently identified among sexual and gender minorities - SGM [4]. Sexual minority women seem to have greater risk for breast cancer and cardiovascular disease relative to heterosexual women $[5,6]$, while sexual minority men have increased risk for sexually transmitted infections compared to heterosexual men [7]. SGM have higher rates of smoking and heavy drinking than the general population $[6,8]$. Depression and anxiety disorders are more prevalent among transgender people [9-11] and sexual minorities [6] when compared to the general population.

In spite of those increased health risks, SGM are less likely to access the care they need [11-14], when compared to non-SGM groups. Those inequities in healthcare provision are mostly influenced by stigma and discrimination $[15,16]$, lack of sufficient health insurance [17], inadequate knowledge or prejudice by healthcare providers [18].

One of the most prominent framework to study SGM health inequities is the minority stress model [19]. This theoretical model addresses the relationship between minority and dominant values in society and resultant conflicts with the social environment that are experienced by minority group members [19-21]. The impact of increased and frequent exposure of SGM to stress, when compared to heterosexual cisgender individuals, highly influences SGM health inequities [22]. Although the extent of legal inequities experienced by SGM has declined in many countries during recent decades, this population still enjoys fewer overall legal rights, protections, and benefits than the non-gender-variant, heterosexual population. Inequities in the law can affect fundamental aspects of SGM lives and might influence their health and ability to access quality health care [23, 24].

For instance, in countries that do not authorize samesex civil unions or marriage, same-sex couples are denied a variety of benefits. In many cases, employersponsored health insurance is not extended to same-sex partners, affecting their access to affordable health care. In addition, SGM are often unable to request medical leave from work to care for an unmarried same-sex partner to the same extent as married couples [25].

The lack of recognition of same-sex civil unions or marriage has other health implications as well. Some studies have identified positive health outcomes associated with same-sex marriage [26, 27]. Riggle et al. [28] conducted a study with 2677 lesbian, gay, and bisexual adults, and identified that same-sex couples in legally recognized relationships experienced fewer depressive symptoms, lower levels of stress and reported less internalized homophobia, when compared with long-term same-sex partners without legal recognition.

Discriminatory polices deeply affect transgender people lives, their health status and healthcare access in numerous ways [29]. For example, legal recognition of one's gender identity is not only essential for a person's dignity, but also necessary to ensure access to the most basic services, including legal identification, formal education, employment, social security, health services, public safety and legal protection [16, 30, 31]. A lack of documents that match an individual's gender identity can result in denial of health and social support services, travel restrictions, bullying, humiliation, and genderbased violence [30, 32, 33].

Transgender individuals encounter unique barriers to access healthcare, when compared to sexual minority men and women, a disparity closely related to legal inequities [33]. Inadequate legislations could jeopardize transgender individuals' access to hormone treatment and gender-affirming surgical procedures, frequently affecting their quality of life and mental health [34].

SGM rights are more likely to advance in democracies where social movements are strong, organized, sufficiently networked, and where religion is less influential in daily life and policy development [35]. However, even strong democracies with well-organized social movements can experience setbacks under highly conservative governmental administrations. For instance, the Trump administration recently removed sexual orientation and gender identity questions from national surveys [36], has banned transgender recruits from joining the military and is revising anti-discrimination regulations - a decision that could decrease SGM access to healthcare, government-funded shelters, economic and social benefits $[12,13,37]$.

In Latin America and Caribbean (LAC) countries, SGM rights have developed in close synchrony with growing social movements [38]. Fights for democratization, after years of dictatorship, presented an important juncture for social movements in several LAC countries [39]. Transition to democratization dramatically changed the political opportunities in LAC countries, which allowed for a different type of interaction between the state and social movements [40].

However, even after the return to democracy, SGM did not have any civil, political or social rights. The reemergence of activism was related, in part, to continued rights-based oppression of SGM under democratically elected governments. For example, in terms of civil rights, three months after Raul Alfonsin was sworn in 
as President of Argentina, "approximately 50 activists were detained in a gay club" [39]. As for political rights, "up until 1990, a law (albeit) unenforced was on the books in Buenos Aires" that essentially banned SGM from voting [40].

In Brazil, the role of social movements during the democratic transition was crucial for ousting the military dictatorship that ruled the country from 1964 to 1985 [41]. During the 1980's the SGM community mainly organized itself to fight the AIDS epidemic, while actively participating in broader discussions and manifestations towards democracy, human rights and health sector reform [42]. However, only in 2013 the country adopted a National Comprehensive Health Plan addressing SGM needs and specificities [43].

Evaluations of major gaps in SGM-related legislation and discriminatory laws can inform policy reforms and guide changes on licensing boards, ethics committees, and other regulatory bodies. The collaborative effort of activists, researchers, health professionals and policy analysts have been pivotal to identify the harmful outcomes of "conversion therapies", informing legislations that ban these "therapies" [44]. However, assessing changes in the legal environment and how it might affect SGM's quality of life is challenging. The causal pathway is frequently long and complex, large-scale changes in legislation do not occur quickly, and there is no gold standard methodology.

Outside of high-income countries, no region has experienced more progress in expanding SGM rights than Latin America [38-40]. While many SGM rights in the United States still involve some degree of legal dispute, in several countries in Latin America laws about samesex marriage and adoption, changing gender on national ID cards, and anti-discrimination laws started in the past decade - many before the US Supreme Court legalized same-sex marriage [45-47].

Nevertheless, worldwide, the highest rate of violence against SGM is found in the LAC region [38]. This article explores this paradigm by analyzing the current scenario of SGM rights in LAC, key successes, major gaps and future challenges.

\section{Methods}

We documented and compared policies addressing SGM rights in LAC countries, following James Mahoney's sociological framework of 'policy path dependency' [48]. This framework allows for the identification of policies based on chronological order, enabling the visualization of changes across countries over time. We hypothesized that previous decisions and policy frameworks could influence changes in future SGM-related legislations. We also assumed the path dependency to follow a 'reactive sequence', instead of a 'self-reinforcing' sequence.
According to Mahoney [48], 'self-reinforcing' sequences are characterized by successive events that reinforce early events, while 'reactive sequences' are marked by backlash processes that transform and sometimes reverse previous events - therefore stimulating policy changes over time through a chain or path of events linked by reactions and counter-reactions. According to Paul Pierson, "initial disturbances are crucial not because they generate positive feedback, but because they trigger a powerful response $(. .$.$) where action and reaction shift$ the system in a new direction, but not one that reinforces the first move" [49].

This methodology is suited to explore policy pathways based on precedent legislations and is particularly adequate to understand how (and if) laws are changed in response to human rights violations. We considered three structural documents in our analysis: the landmark Universal Declaration of Human Rights - UDHR [50], adopted by the UN General Assembly in 1948, as well as the International Covenant on Civil and Political Rights (ICCPR) and the International Covenant on Economic, Social and Cultural Rights (ICESCR), both adopted by the UN General Assembly in 1966 [51, 52]. These three documents - the UDHR, ICCPR, and ICESCR - are referred collectively as the "International Bill of Human Rights". The documents form the normative basis from which SGM rights were evaluated here, as an interconnected process across LAC countries. This methodological framework allowed us to conceptualize SGM policy as a social process, following a sociological dynamic of "increasing returns", or positive feedback [53]. Furthermore, it integrated competing ideas, values and legislations from the different countries and sub-regions under analysis.

\section{Theoretical framework: path dependency in reactive sequences}

The use of a path dependence methodology enables policy processes to be analyzed taking into account the significance of sequencing in policy development and policy changes. This framework was utilized to: (1) identify what aspects might define, review or change policies towards SGM from LAC countries; (2) create a reference framework to better understand the policy-making processes related to SGM rights; and (3) trace a possible interface between political changes, internal and external pressures and the (possible) adoption of new policies.

Our study considered the UDHR [50] as a critical juncture policy that influenced SGM rights protections internationally and within the LAC region, followed by ICCPR and ICESCR [51, 52]. Policy and time were key variables in our analysis, herein presented in diagrams that facilitate the visualization of their supposed interdependency in SGM rights [48]. We evaluated each 
selected policy to identify putative inputs, advantages, disadvantages and possible effects on other policies related to SGM rights in each country, sub-region and LAC.

\section{Data collection and search strategy}

The first step, the identification stage of our search, was to extract relevant data from governmental policies and legislation that address SGM from all 33 LAC countries. Data was extracted from original legal documents published by each country. The search was not limited by language or publication year, as one major goal was to create a timeline of policies. The scope of SGM polices was narrowed to include two broad categories: legal protections addressing same-sex couples, and anti-discrimination laws.

Legal and policy documents retrieved from governmental websites or provided by governments were included if deemed eligible, whereas programs and strategies developed by non-governmental organizations were excluded. Identified laws were eligible regardless of publication date, and constitutions were included because of their fundamental role in each country's legislations. Policy documents and governmental strategies were compared to and aligned in a timeline framework, organized by three sub-regions: the Caribbean (Antigua and Barbuda, Bahamas, Barbados, Cuba, Dominica, Dominican Republic, Grenada, Haiti, Jamaica, St. Kitts and Nevis, Saint Lucia, St. Vincent and the Grenadines, Trinidad and Tobago), Mesoamerica (Belize, Costa Rica, El Salvador, Guatemala, Honduras, Mexico, Nicaragua, and Panama) and South America (Argentina, Bolivia, Brazil, Chile, Colombia, Ecuador, Guyana, Paraguay, Peru, Suriname, Uruguay, Venezuela). Our study did not include overseas territories of the United Kingdom, the Netherlands, France or the USA.

\section{Data analysis}

Our analysis included the following steps: (1) data extraction (date and description of legislation) for each country, (2) organization of legislation by sub-region (the Caribbean, Mesoamerica or South America), (3) aggrupation of legislations according to key domains under analysis, and (4) data analysis.

The domains analyzed addressed two broad categories: (1) legal protections addressing same-sex couples (decriminalization of same-sex acts among consenting adults, legal recognition of same-sex unions, same-sex marriage, adoption by same-sex couples), and (2) antidiscrimination laws (SGM allowed to serve openly in the military and anti-discrimination laws related to sexual orientation, gender identity and/or expression).

We conducted an analysis of policy path dependency in reactive sequences within each LAC sub-region. The strategy enables the identification of temporal patterns of policy-making, inter-relations between policies from the same country and possible temporal and political influences between countries and across a selected region. The strategy also allows for a better visualization of complex policy processes, such as those related to SGM rights. Policies that addresses highly vulnerable and stigmatized sub-groups tend to be deeply influenced by social, cultural and political changes, as well as national, regional and international scenarios [54]. This strategy was also adopted to (1) create a reference analysis framework, (2) identify changes in local legislations, following other countries new/updated laws, and (3) analyze the impact of different political scenarios (e.g. progressive vs. conservative) in SGM legislation in the region, following the reactive sequence theory.

The initial and seminal policy considered within our analysis was the UDHR [50], followed by ICCPR and ICESCR $[51,52]$ given that these documents were milestones that influenced international, regional and national policies addressing fundamental human rights.

Time and policy are two variables presented on a timeline to show their putative overlap, therefore facilitating the visualization and analysis of trends. This strategy allowed us to identify core policies as historical sequences and patterns, sometimes linear, sometimes not - therefore in synchronicity with the chosen theoretical framework. Current SGM-related policies were considered as a result of previous events, tracked using this framework.

\section{Results}

We identified 105 documents through governmental sources and 42 additional reports from selected entities (Organization of American States, United Nations, Amnesty International, and Human Rights Watch). No duplicates were identified; therefore, we included 147 documents in the screening stage. During the screening, we excluded 61 records that did not mention our study population (SGM), did not describe any SGM-related legislation or were unrelated to the LAC region. The final number of policies initially included in our analysis was 86. After the manuscript initial peer-review, two new legislations were approved in 2019 (same-sex marriage in Ecuador and SGM-hate crime in Brazil). Therefore, we included 88 policies and international reports in our analysis. A full list of the policy documents analyzed in this paper is available (Additional file 1). Please see our PRISMA flow chart (Fig. 1) for the detailed search strategy stages and results. The countries were organized by sub-regions (Caribbean, Mesoamerica and SouthAmerica), to account for heterogeneity across LAC countries and to compare countries with more similar social and cultural characteristics. With these inputs, we created a timeline of policies related to SGM population 


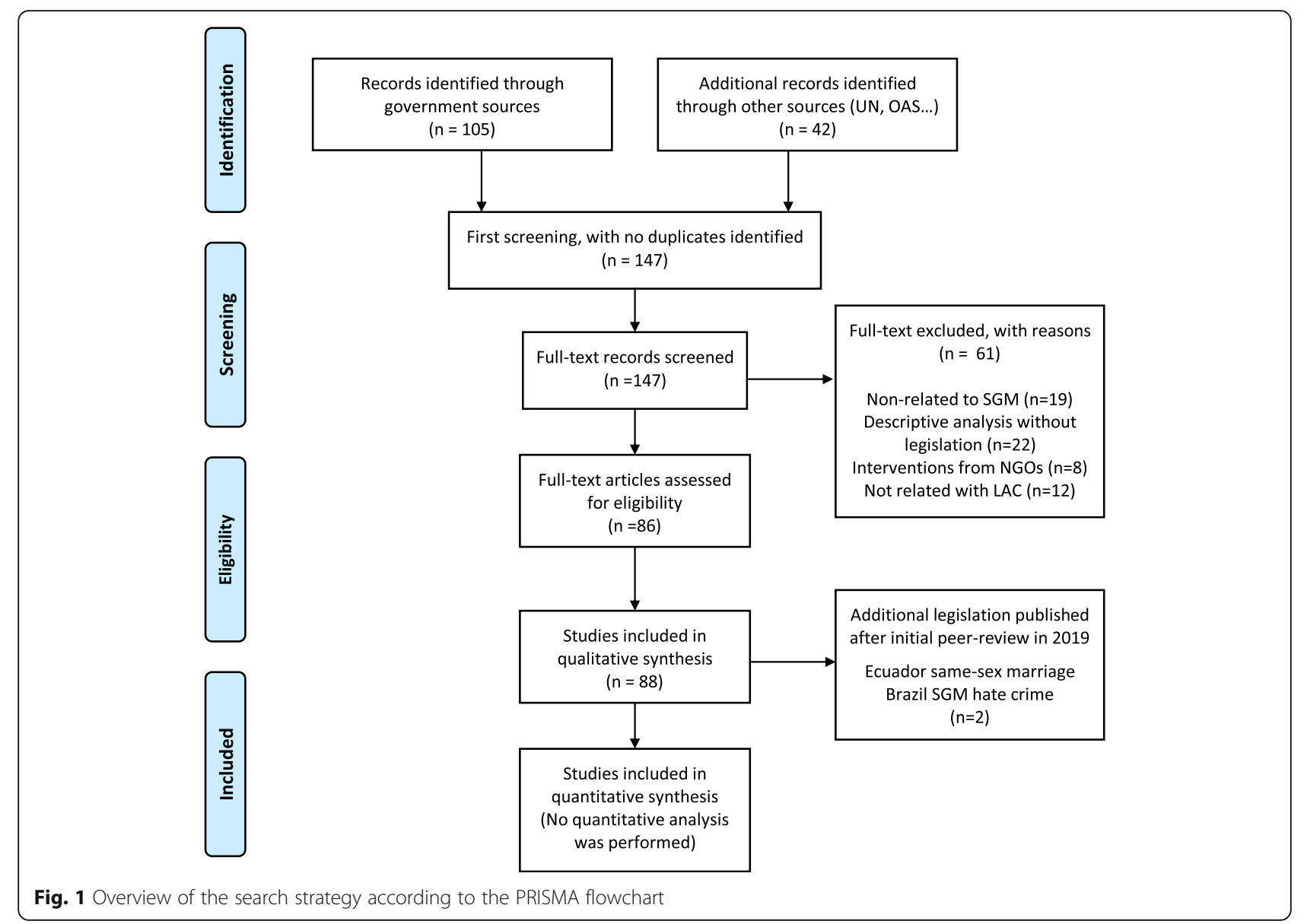

for each country, organized by the three sub-regions under analysis (Fig. 2).

Table 1 summarizes the existing laws addressing SGM in each LAC country by sub-regions. All selected documents and reports are available at an Open Science Framework page (https://osf.io/4zq7j/files/?view_only= e139c918d77c4f14a120658edfd25804).

\section{The Caribbean region}

Discriminatory laws against SGM people are particularly common in the Caribbean region. The majority of Caribbean countries have versions of "buggery" and gross indecency laws, relics of British colonialism, that prohibit same-sex conduct between consenting adults. Among the countries evaluated $(n=13)$, the majority has laws that, when violated, include 10 years to life imprisonment, fines and/or hard work: Antigua and Barbuda, Barbados, Dominica, Grenada, Jamaica, St. Kitts and Nevis, St. Lucia, and St. Vincent and the Grenadines (Table 1). Although these laws are vaguely worded and rarely enforced in criminal prosecutions, the legislation contributes to widespread discrimination, violence, stigma and prejudice against SGM in the region [55].
Section 9 of the Sexual Offences Act of Barbados criminalizes the act of "buggery", defined by the Barbadian courts as "anal sex between men or between a man and a woman". Section 12 criminalizes "serious indecency," which is defined as any act by anyone "involving the use of the genital organs for the purpose of arousing or gratifying sexual desire." These acts are criminalized notwithstanding the consent of the participants. The maximum penalty for buggery is life imprisonment; the maximum penalty for an act of serious indecency (involving a partner above the age of 16) is 10 years in prison (Table 1).

In Haiti, there is no law criminalizing consensual same-sex sexual acts, but Article 227 of its criminal code prohibits vagrancy, with a specific mention in the code to transgender people. In 2017, the Haitian Senate passed a Bill listing homosexuality, alongside child pornography and incest, as reasons to deny a citizen its 'Certificat de Bonne Vie et Moeurs', a document required by employers and universities. In the same year, another Bill was passed to ban gay marriage and any public advocacy of SGM rights [48]. Only Cuba and Bahamas allow SGM to serve openly in the military. Cuba is the single country in the Caribbean with anti-discrimination laws 
a. Selected SGM rights in the Caribbean, 1998-2018

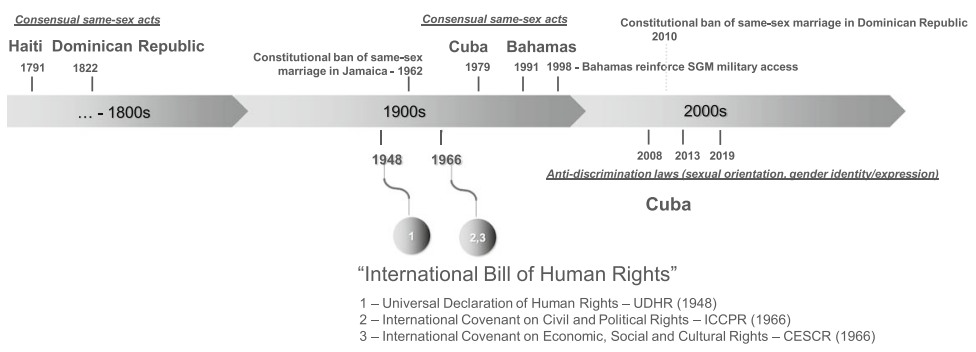

b. Selected SGM rights in Mesoamerica, 1998-2018

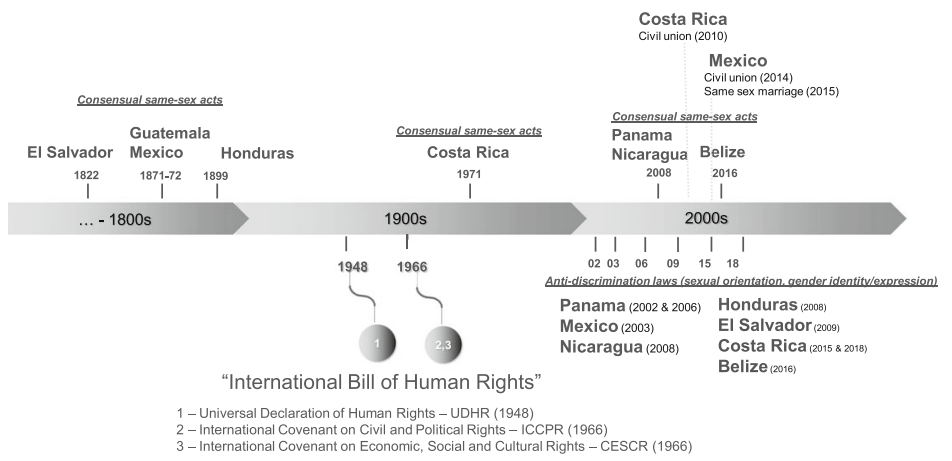

C. Selected SGM rights in South America, 1998-2018



Fig. 2 a Selected SGM rights in the Caribbean, 1998-2018. b Selected SGM rights in Mesoamerica, 1998-2018. c Selected SGM rights in South America, 1998-2018

related to sexual orientation (2014) and gender identity/ expression (2008). Since 2008, Cuba's government provides integral medical care (including gender-affirming surgeries and hormonal treatment) through the National Health System. Transgender people can change their name and gender in legal documents, but need to submit the petition to a local tribunal, including a medical certification that the petitioner has undergone genderaffirming surgery (Table 1).

The key international documents that guided our analysis (UDHR [1948], ICCPR [1966] and ICESCR [1966]) do not seem to have influenced policies targeting SGM in most countries in the Caribbean. After the publication of the 'International Bill of Human Rights', only Cuba implemented a broad range of new policies allowing consensual same-sex acts (1979), transgender individuals to change their legal name and gender (2008), workrelated SGM anti-discrimination laws (2014), and overall SGM anti-discrimination laws (2019). Besides Cuba, the Bahamas also implemented a new legislation allowing consensual same-sex acts (1991) and reinforced the right of SGM to serve openly in the military (1998). In 


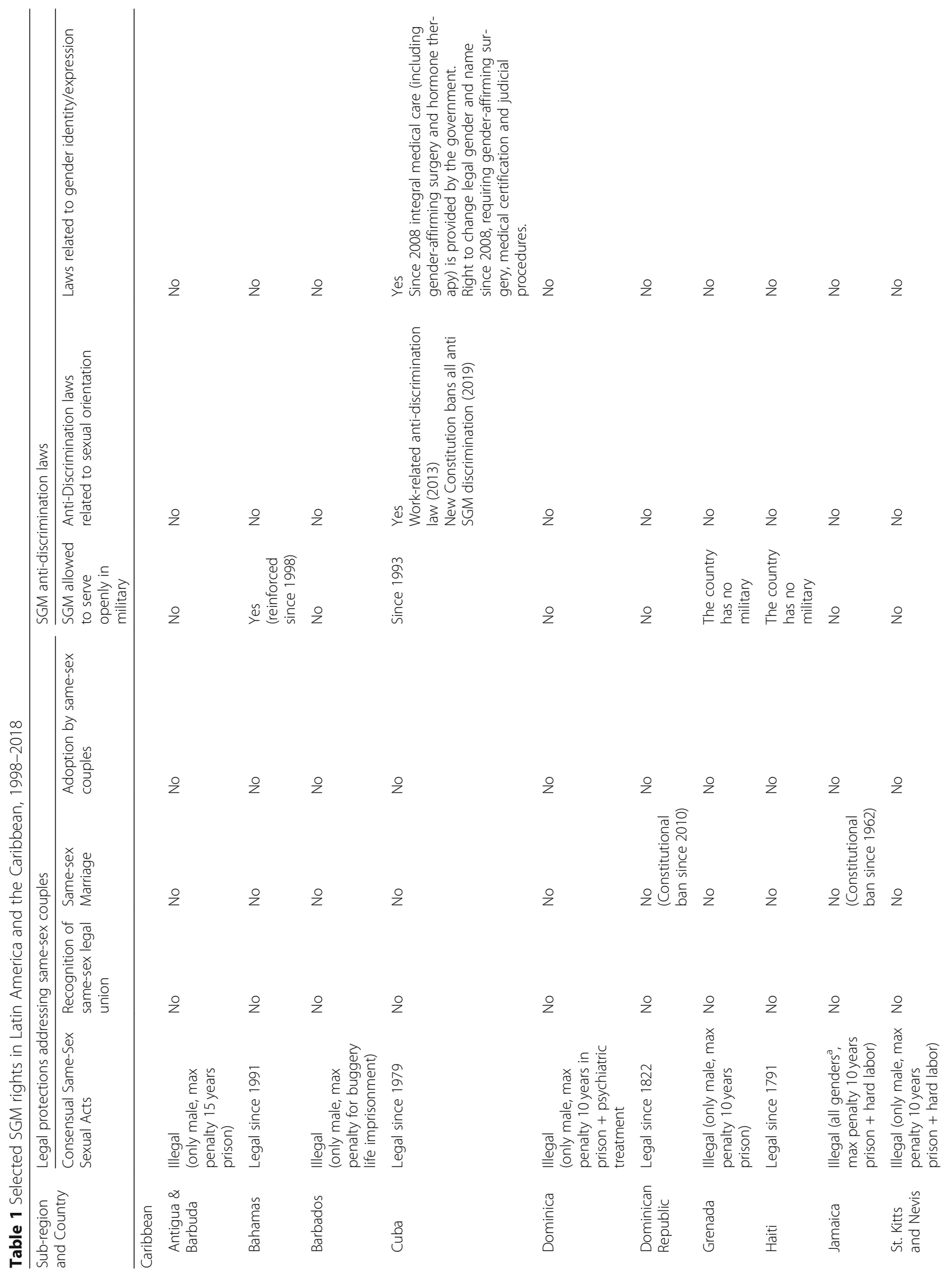




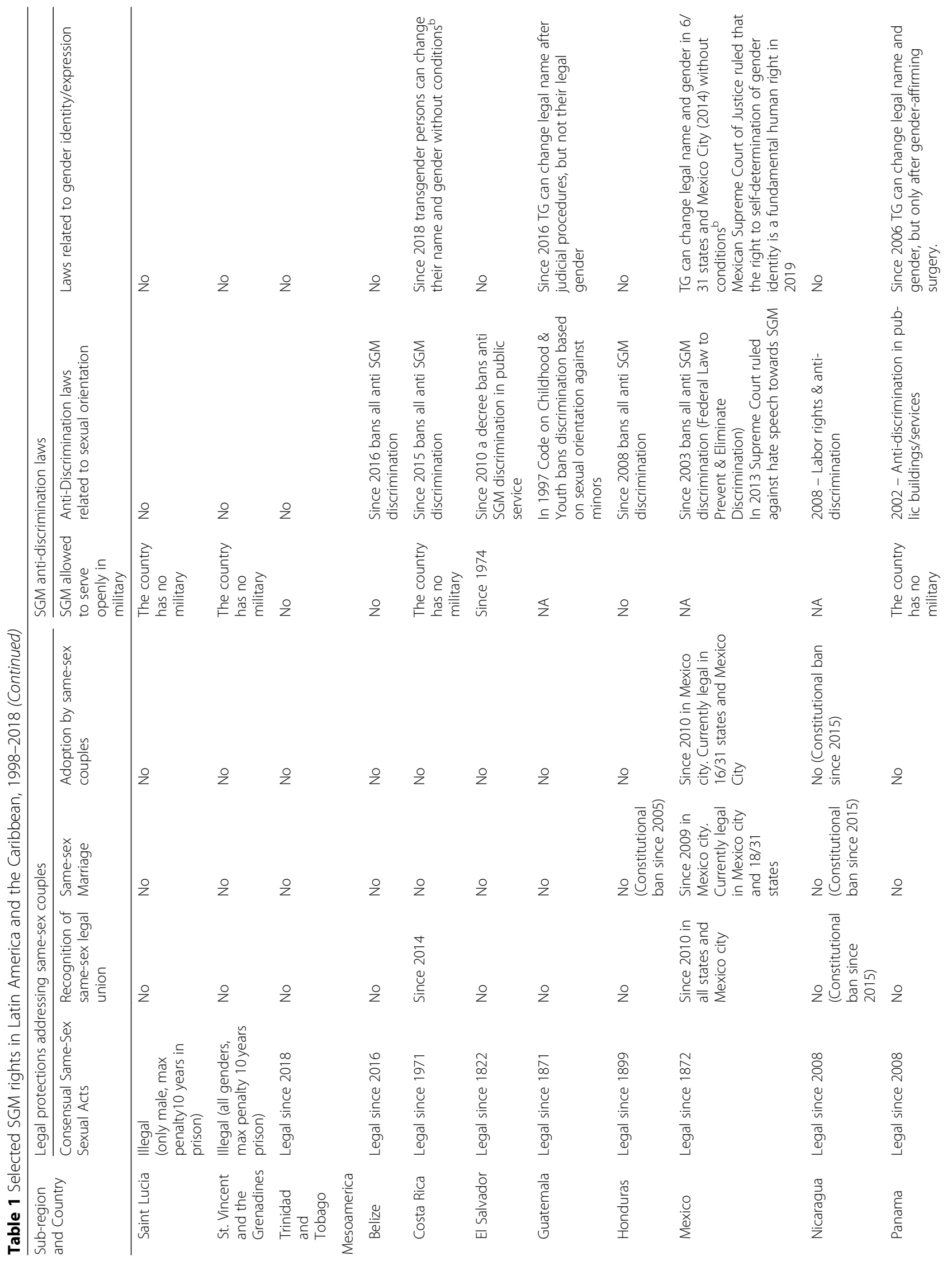




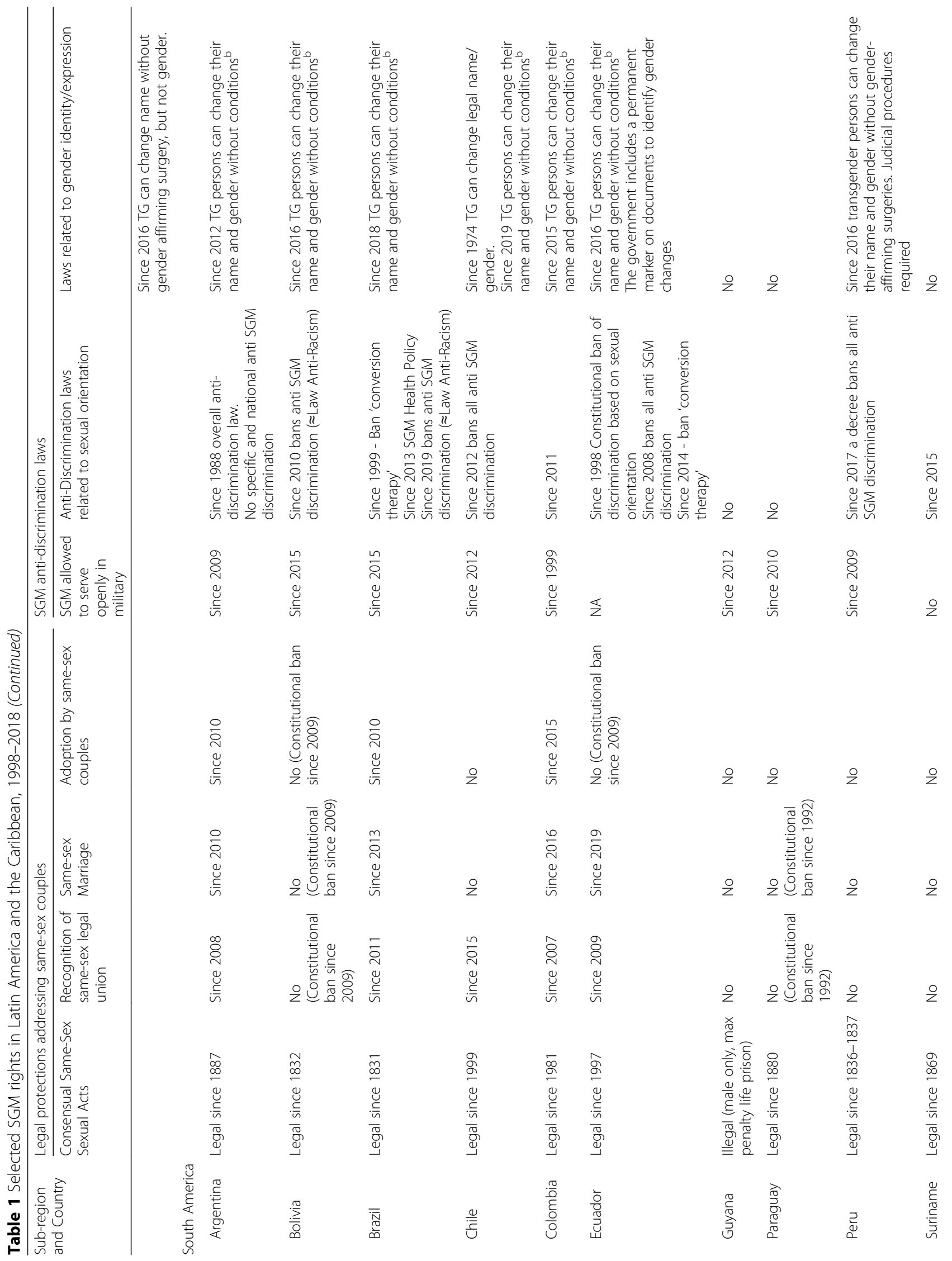




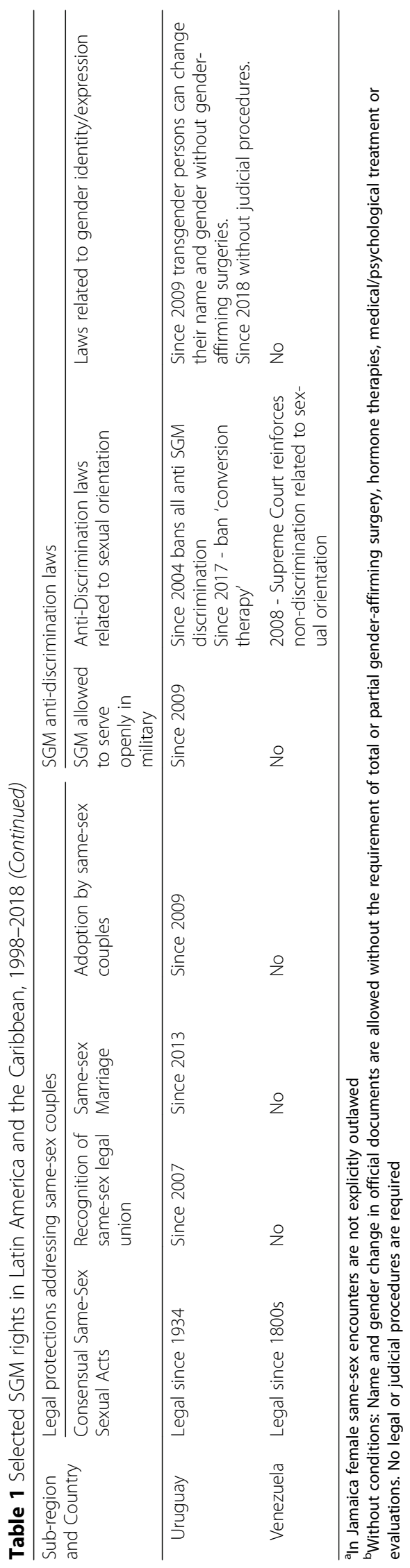


contrast, after the publication of the 'International Bill of Human Rights', two countries adopted a constitutional ban against same-sex marriage: Jamaica (1962) and the Dominican Republic (2010).

SGM prosecutions are not common in the region, but the overall lack of legal protection contributes to an environment that condones discrimination, stigmatization, and violence towards SGM. These laws (or the lack of legislation against discrimination) have frequently been utilized to justify arbitrary detention, police abuse, extortion and torture. SGM who are incarcerated or otherwise implicated in the justice system are particular targets for sexualized violence and administrative punishment while in custody.

Our analysis identified that discriminatory legislations (Table 1) negatively influence SGM rights the Caribbean, making them ready victims of discrimination, violence, and other human rights violations. The majority of Caribbean countries do not seem to be influenced by the 'International Bill of Human Rights' and its core principles to promote and protect human rights of individuals and more vulnerable groups, such as SGM (Fig. 2a).

To some extent, Cuba remains a single exception in this scenario. As of August 2019, the country signed in 2008 the ICCPR and ICESCR, but did not ratify these treaties. In spite of the identified progress in the field of SGM-rights, the Amnesty International and Human Rights Watch have reported several human rights violations in Cuba. The state tight controls freedom of expression, and frequently employ arbitrary detention to harass and intimidate critics, independent activists, political opponents and human rights defenders who attempt to document abuses - including SGM citzens. In 2019, the government canceled the annual LGBT Pride Parade and arrested SGM activists who organized an unauthorized march.

\section{Mesoamerica region}

We included in this sub-region seven countries from Central America (Belize, Costa Rica, El Salvador, Guatemala, Honduras, Nicaragua and Panama) and Mexico. Same-sex sexual acts among consenting adults has been legal in four countries since the 1800's (El Salvador, Guatemala, Honduras and Mexico). A few years after the publication of the 'International Bill of Human Rights', same-sex sexual acts among consenting adults became legal in Costa Rica (1971). However, the same legislation was only adopted in Nicaragua and Panama in 2008, followed by Belize in 2016 (Fig. 2b).

In the vast majority of countries in Mesoamerica, same-sex couples do not have equal marriage rights and are not allowed to adopt as a couple. In January 2015, the Supreme Court of Mexico handed down a landmark decision in which the legal definition of marriage was changed to encompass same-sex couples. After this decision, the law restricting marriage to a man and a woman was considered unconstitutional. However, in several states of Mexico, same-sex couples still have to request an injunction ("Amparo") from a judge to marry, a process not required for opposite-sex couples. In Costa Rica, same-sex legal unions are recognized (2014). On the opposite end of the spectrum, although same-sex sexual activity among consenting adults is legal in Honduras and Nicaragua, both countries have constitutional bans against same-sex marriage. In Honduras, same-sex marriages, de facto unions and adoption by same-sex couples were constitutionally banned in 2005 . In Nicaragua, after the adoption of a new Family Code (2015), marriage, civil union or adoption by same sex couples was prohibited. In Mexico, only 16 states (of 31) and Mexico City allow adoption by same-sex couples, and until the end of this review (August 2019) there was no national legislation addressing marriage equality (Table 1). In contrast, in April 2017, lawmakers from Guatemala presented a legislative proposal to explicitly prohibit same-sex marriage and restrain public schools from teaching about sexual diversity and gender identity - the proposal was supported by over 30,000 signatures.

Four countries implemented some degree of anti-SGM discrimination laws, including labor rights legislations in Nicaragua (2008), anti-discrimination laws in public buildings in Panama (2002) and El Salvador (2010), and legislation protecting SGM youth in Guatemala (1997). Four countries ban all discrimination based on sexual orientation and gender identity: Mexico (2003), Honduras (2008), Costa Rica (2015) and Belize (2016).

Only Costa Rica allows transgender people to change their name and gender on documents without surgeries, medical/psychological evaluations or judicial permission. Since 2006, Panama allows transgender persons to change their legal name and gender, but only after gender affirming surgery. Since 2016, transgender people can change their name without needing any surgery in Panama, but not their gender. In Guatemala, transgender persons can change their legal name after judicial permission, but not their legal gender (2016). In Mexico, there is no national legislation addressing the needs and specificities of transgender people. Since 2015, transgender people can change their legal name and gender in Mexico City without the need of psychological/medical evaluations or gender-affirming surgery. Six states (of 31) adopted similar legislations until the end of this review (August 2019). In May 2019, the Mexican Supreme Court of Justice decided that the right to selfdetermination of gender identity is a fundamental human right; therefore, a new scenario might be implemented towards transgender rights in the entire country. (Table 1). 
In May 2016, the government of Costa Rica questioned the Inter-American Court of Human Rights, of the Organization of American States (IACHR/OAS) about their obligations related to transgender citizens who requested to change their names and gender in official documents. They also inquired if the country should develop a specific legislation to recognize the economic rights of same-sex couples [56]. In 2018, the IACHR/ OAS affirmed, through Advisory Opinion 24/17, that all State Members should assure that same-sex couples have access to civil marriage and all related rights. The document also requires State Members to offer a fast, easy and cost-free process to allow transgender people legally change their name and gender in accordance with their self-perceived gender identity [56]. Following IACHR/OAS Advisory Opinion 24/17, in 2018 Costa Rica implemented a new legislation that allows transgender person to change their legal name and gender without the need of medical/psychological evaluation, judicial permission or gender-affirming surgery.

However, in Mesoamerica systemic discriminatory legislations seems to exacerbate the discrimination towards SGM, within a social and cultural context of strong sexism, gender stereotypes and high rates of violence. This scenario is driving hundreds of SGM from Mesoamerica to leave their home countries, usually looking for refuge in Mexico or in the United States [57]. According to the Office of the United Nations High Commissioner for Refugees (UNHCR), nearly $90 \%$ of SGM asylum seekers and refugees from Central America report experiences of sexual and gender-based violence in their home countries [58].

\section{South America region}

Same-sex sexual acts among consenting adults has been legal in six countries of South America since 1800's (Argentina, Brazil, Bolivia, Paraguay, Peru, and Suriname). Four countries legalized same-sex consensual acts during the 1990's: Chile, Colombia, Ecuador and Uruguay. In Venezuela same-sex sexual acts was never illegal, but a law related to 'Vagrants and Thugs' ('Ley de vagos y maleantes') was occasionally applied to SGM engaged in sex work. The Supreme Court of Justice declared this law unconstitutional in 1997. Same sex acts between two men is illegal in Guyana and could lead to imprisonment for life (Fig. 2c).

Six countries recognize same sex legal unions: Argentina, Brazil, Chile, Colombia, Ecuador and Uruguay. Argentina, Colombia, Brazil and Uruguay also recognize same-sex marriage nationally and allow same-sex couples to adopt. Following IACHR/OAS Advisory Opinion 24/17 [56], in July 2019 same-sex marriage became legal in Ecuador, but the country does not allow same-sex couples to adopt. As of August 2019, only two countries in the region have a constitutional ban against same-sex marriage: Paraguay (1992) and Bolivia (2009).

Guyana is the only country in South America, and the only country in the Americas outside the Caribbean, where homosexual acts (as well as heterosexual anal and oral sex) are illegal. Guyana does not recognize same-sex legal unions; neither allow same-sex couples to adopt. In the country, transgender people cannot change their legal name and gender, and there is no SGM antidiscrimination legislation. In November 2018, Guyana's final court of appeal ruled that a law against crossdressing violates the constitution of Guyana, voiding it. Guyana, Paraguay, Suriname and Venezuela are the countries where SGM people have fewer rights in the region (Table 1).

Transgender individuals can change their legal name and gender in Argentina, Bolivia, Brazil, Chile, Colombia, Ecuador and Uruguay without the requirement of surgeries, medical/psychological evaluations or legal procedures. In Peru, transgender people can change their name and gender, but they need to apply before a judge - no medical/psychological evaluations or surgeries are required. Those legislations were implemented after the 'International Bill of Human Rights', mostly during the last two decades (Fig. 2c).

Overall, legislation to protect SGM rights in South America have undergone fundamental and positive transformations during the last decade. The majority of countries in South America have legal protections against discrimination towards SGM people and consider hate crimes based on sexual orientation and/or gender identity as an aggravating circumstance. Eight countries (of 12) allow transgender people to change their name and gender on legal documents without surgeries or medical/psychological evaluations, just one requiring judicial permission (Table 1).

Despite the expanding federal laws to protect SGM, the region registers one of the highest rate of violence and hate crimes against SGM people. Whichever the legal framework, and regardless of whether it includes specific hate crime or hate speech laws addressing SGM people, each country need to ensure that criminal legislation relating to SGM discrimination and violence is diligently applied. The existence of laws addressing SGM rights violation is important, but if available legislation is not effectively enforced a mutually reinforcing cycle of lack of reporting and low conviction rates continues. The region countries need to created effective mechanisms to enforce these laws. In addition, the majority of countries do not classify crimes based on sexual orientation and/or gender identity as hate crimes, with more severe penalties. The lack of proper law implementation might be a key factor influencing high rates of violence against SGM in the region. Brazil, for instance, has the 
highest rate of hate crimes against SGM in the world crimes frequently unprosecuted and unpunished. Only in June 2019, the Brazilian Supreme Court decided to consider discrimination on the grounds of sexual orientation or gender identity equivalent to racism, making those crimes punishable under the country's more severe anti-racism law.

In recent years, highly conservative groups have also increased their political influence in the South America region. In January 2019, Brazil's far-right president, Jair Bolsonaro, was sworn into office. Under Mr. Bolsonaro administration, an ultra-conservative agenda is being implemented, deeply decreasing the country progressive support towards diversity and human rights $[59,60]$. The government authorized severe cuts in federal funding for education, health, research and social support strategies, directly affecting SGM people and other vulnerable minorities [42].

In Venezuela, Nicolás Maduro was first elected president in 2013, and re-elected in a controversial election in 2018. Until mid-2019, over 4 million people have left Venezuela to escape violence, insecurity, life threats, lack of food, medicine and essential services - the percent of those who self-identify as SGM is unknown [61]. After a decade of leftist government, around mid-2010 a rightwing political phenomenon emerged in South America. Currently the majority of countries in the region are controlled either by center-right (e.G. Argentina), right wing leaders (e.g. Brazil) or by repressive dictators (Venezuela). The near future of the region is unknown, but if this highly conservative political agenda influence human rights legislation currently available, setbacks in SGM legal protections are likely.

\section{Discussion}

Recently the IACHR/OAS Advisory Opinion 24/17 stated that all signatory member States of the of the American Convention on Human Rights ('Pact of San Jose', signed in 1969) should assure that same-sex couples have access to civil marriage and all related rights. The Advisory Opinion also requested State Members to assure that adequate and efficient gender identity legislations are available to their transgender citizens [56].

In terms of marriage equality, this IACHR Advisory Opinion 24/17 could be an important step forward to promote SGM rights in the LAC region. However, among 20 states from LAC that recognize the IACHR and the Court mandatory jurisdiction, 14 have not yet legalized same-sex marriage: Barbados, Bolivia, Chile, Costa Rica, Dominican Republic, El Salvador, Guatemala, Haiti, Honduras, Nicaragua, Panama, Paraguay, Peru, and Suriname [56]. Trinidad and Tobago and Venezuela had both ratified the Court's jurisdiction, but withdrew its ratification when they denounced the American Convention in 1998 and
2012, respectively - both countries do not recognize same-sex marriage. Grenada, Dominica and Jamaica ratified the 'Pact of San Jose', but do not recognize the IACHR mandatory jurisdiction - those countries likewise do not recognize same-sex marriage.

IACHR's Advisory Opinion 24/17 also addressed legal gender recognition, recommending all signatory countries to adopt a simplified process allowing anyone to change their name and affirm their self-perceived gender identity in public records and documents. According to IACHR, the process should be confidential, free, and not require surgery or hormone treatment [56]. However, until August 2019, transgender people are unable to change their gender in public records and legal documents in several LAC countries - mostly in the Caribbean and Mesoamerica. Other countries allow those changes only through a complex, costly and timeconsuming process involving judicial permission and court appearances (as in Guatemala), or only after gender-affirming surgery (as in Panama and Cuba). Other countries, like Ecuador, allow transgender citizens to change their name and gender, but include a permanent marker on the person's documents - a stigmatizing policy.

On the opposite side of the spectrum, the majority of countries from South America allow their transgender citizens to change name and gender in legal documents with a fast, easy and inexpensive manner. On February 3rd, 2018, the Brazilian Supreme Court authorized gender modification on civil documents without the need of any medical evaluation or gender-affirming surgery. The Brazilian Superior Electoral Court allowed transgender candidates to use their preferred name and pronouns during the 2018 elections. In June 2019, the Brazilian Supreme Court made homophobia and transphobia crimes similar to racism, a hate crime [62].

In most countries where transgender people are refused legal recognition of their gender identity, this might lead to further human rights violations, impacting their access to education, employment, healthcare, social security, and legal protection [29, 30]. Many countries that do permit the modification of gender markers on identity documents impose abusive requirements, such as forced or otherwise involuntary surgery, medical diagnosis, long, costly and complicated judicial procedures [31, 32]. The translation of IACHR Advisory Opinion 24/17 into reality will require multidisciplinary work and strong political will in the LAC region. However, in the past few years conservative movements have resulted in a strong backlash against SGM rights across the Americas. In 2016, a conservative movement contributed to blockage of a constitutional Bill on marriage equality in Mexico. In 2017, the conservative parties from Peru derailed a proposed SGM-inclusive education curriculum. Recently, people have rallied in 
Paraguay and Ecuador, claiming a need to defend the "traditional family" from so-called "gender ideology" [57, 63, 64]. Right wing and ultra conservative presidents have been elected in Argentina (2015), Chile (2017), and Brazil (2018).

While studying the uneven evolution of SGM rights in the LAC region, it is possible to state that the existence of pro-SGM movements and progressive legislations have been important but not sufficient to advance SGM rights. The expansion of SGM rights and efforts to advance those rights have produced a persistent confrontation between right-based social movements, the State and conservative/religious organizations. In the region, religiosity and faith-based groups continue to be strong veto players and frequently influence the implementation of more inclusive SGM-rights legislations [65].

Our analysis demonstrated that countries located in the Central America and the Caribbean provide less constitutional rights to their SGM citizens. SGM related social movements are recent within this region and started in the 1990's to fight the AIDS epidemic. Until nowadays SGM-rights efforts in the region face strong opposition from governments, religious organizations and the society at large [38-40].

\section{Policy challenges, opportunities and the way forward}

This review discussed the transformation of SGM rights in Latin America and the Caribbean. The different scenarios provide important examples of how social movements, institutions and governments can (and should) work together to improve SGM rights. Social movements within the LAC region have made impressive advances in the legal environment of many countries, despite the prevalence of adverse cultural attitudes, conservative norms and prejudice.

While there has been an undeniable progress in many countries, stagnation on the legal status of SGM people is also visible in the LAC region. In some countries (e.g., Argentina, Uruguay, Brazil) and in some cities (e.g., Mexico City), the legal status of SGM rights is ahead of some of the most advanced and democratic nations of the world - with same-sex marriage or civil unions, anti-discrimination and hate crime laws, and progressive legislations addressing transgender rights. In other countries (mostly in the Caribbean and Central America), the legal status of SGM rights remains underdeveloped. Sometimes this unevenness is perceived in the same country. Brazil, for instance, provides extensive legal protections to SGM, but has also one of the highest rates of SGM violence and murders worldwide [59, 60].

Reasons for this disparity are complex and represent a clear indication that progressive legislation is not sufficient to advance SGM quality of life. In a social, cultural and political scenario of entrenched prejudice, discrimination and rampant violence, SGM-related legislation is frequently not enforced or even observed. Few Latin American employers have proactive policies towards SGM employees. Marriage continues to be defined, constitutionally in some cases, as the union between a man and a woman. Transgender people are frequently victims of harassment, discrimination, sexual and physical violence (committed by police officers, other State officials and non-State actors). Although the legislation exists (in some countries), the cultural and social environment is unwelcoming and constantly dangerous for SGM in the LAC region.

\section{Conclusion}

International courts are not be able to protect the rights of SGM people due to region and country-specific legislations. Political, cultural and societal pressures constantly influence how (and if) legislation and national policies underpin a rights based approach or not. Unfortunately, just a few national and subnational courts in the LAC region respect all signed international laws and decrees, as clearly presented here. However, in countries with an independent and impartial judiciary, where governments understand and respect human rights standards, those international laws should contribute and inform a necessary pathway to change.

Recent advances show good prospects, but the processes of constructing non-discriminatory public policies towards SGM face several barriers in each country. Cultural norms and the overall political environment highly influence SGM rights in the region and worldwide. We conclude that SGM rights in the LAC region need to be improved. Governments and the civil society should work together, in order to tackle the unacceptable levels of violence and human rights violations towards SGM in the region. It is also pivotal to increase this population access to health, education, social support, legal protection and justice.

The policy synthesis provided here could guide LAC policymakers, political and government leaders, advocates, lawyers, policy makers and activists to identify local and regional gaps in SGM-related rights. Our study can also underscore the need to advocate for better legislations that respect the rights and dignity of all. The Universal Declaration of Human Rights [50] states in Article 2: "Everyone is entitled to all the rights and freedoms set forth in this Declaration, without distinction of any kind." According to the United Nations [66], failure by State authorities to investigate and punish SGMrelated discrimination and violence "is a breach of the State's obligation to protect everyone's right to life, liberty and security of person, as guaranteed by article 3 of the UDHR and articles 6 and 9 of the ICCPR". 
Regardless, in 2019 a substantial percentage of signatory Member States fail to protect the human rights of their SGM citizens. LAC countries have achieved several successes in this field, and have the potential to foster SGM rights in the next years. The question is whether local governments and lawmakers will actually commit their efforts to protect human rights and decrease the unacceptable abuses towards SGM identified in the Latin America and the Caribbean.

\section{Supplementary information}

Supplementary information accompanies this paper at https://doi.org/10. 1186/s12914-019-0217-3.

Additional file 1. List of Selected documents

\section{Abbreviations}

IACHR: Inter-American Court of Human Rights; LAC: Latin America and the Caribbean; LGBTI: Lesbian, Gay, Bisexual, Transgender; OAS: Organization of American States; UNHCR: Office of the United Nations High Commissioner for Refugees

\section{Acknowledgements}

Dr. Cardoso acknowledges the support of the Department of International Law of the Secretariat for Legal Affairs at OAS, during the XLIV Course on International Law in 2017. Dr. Malta acknowledges the support of the Brazilian Chamber of Deputies, provided during the second mandate of Federal Deputy Jean Wyllys to the Oswaldo Cruz Foundation (FIOCRUZ).

\section{Authors' contributions}

MM and RC conducted the literature review and the analysis. MM, RC, SL and KW drafted the manuscript. MDDS developed the Open Science Framework and revised the manuscript methods description. LM, JGJ, MS, and $\mathrm{BB}$ extracted the data, organized the results and provided feedback on the final draft of the manuscript. All authors read and approved the final manuscript.

\section{Funding}

Not applicable.

\section{Availability of data and materials}

All selected documents are available at an Open Science Framework: https:// osf.io/4zq7j/?view_only=e139c918d77c4f14a120658edfd25804

\section{Ethics approval and consent to participate}

Not applicable.

\section{Consent for publication}

Not applicable.

\section{Competing interests}

Monica Malta is Associate Editor for BMC Public Health and BMC International Health and Human Rights. The other authors declare that they have no conflict of interest.

\section{Author details}

${ }^{1}$ Faculty of Medicine, Department of Psychiatry, University of Toronto, Toronto, 33 Russell Street / Room RS 2035, Toronto, Ontario M5S 2S1, Canada. ${ }^{2}$ Institute for Mental Health Policy Research, Centre for Addiction and Mental Health, Toronto, ON, Canada. ${ }^{3}$ Department of Social Science, National School of Public Health, Oswaldo Cruz Foundation (ENSP/FIOCRUZ), Rio de Janeiro, Brazil. ${ }^{4}$ Department of International Law, Organization of American States (OAS), Washington, DC, USA. ${ }^{5}$ Department of Epidemiology and Quantitative Methods in Health, Sergio Arouca National School of Public Health (DEMQS-ENSP), FIOCRUZ, Rio de Janeiro, Brazil. 'Rio de Janeiro Federal Institute of Education, Science and Technology, Belford Roxo, RJ, Brazil. 'UN Women Brazil, Civil Society Advisory Group, Brasilia, DF, Brazil.
${ }^{8}$ Felipa de Sousa Women's Group, Rio de Janeiro, RJ, Brazil. ${ }^{9}$ Brazilian National Association of Transgender and Travesties (ANTRA), Salvador, BA, Brazil. ${ }^{10}$ Department of Social Science, Sergio Arouca National School of Public Health (DCS-ENSP), FIOCRUZ, Rio de Janeiro, Brazil. ${ }^{11}$ Center for Health Policy and Inequalities Research, Duke Global Health Institute, Duke University, Durham, NC, USA.

Received: 21 August 2018 Accepted: 16 October 2019

Published online: 06 November 2019

\section{References}

1. CSDH. Closing the gap in a generation: health equity through action on the social determinants of health. Final report of the commission on social determinants of health. Geneva: World Health Organization; 2008.

2. Marmot M, Friel S, Bell R, Houweling TA, Taylor S. Commission on Social Determinants of Health. Closing the gap in a generation: Health equity through action on the social determinants of health. Lancet. 2008;372(9650): $1661-9$.

3. Marmot M. Social determinants of health inequalities. Lancet. 2005 Mar 1925: 365(9464):1099-1104

4. Institute of Medicine. The health of lesbian, gay, bisexual, and transgender people: building a foundation for better understanding. Washington, DC: National Academies Press; 2011.

5. Case P, Austin SB, Hunter DJ, Manson JE, Malspeis S, Willett WC, Spiegelman D. Sexual orientation, health risk factors, and physical functioning in the Nurses' health study II. J Women's Health (Larchmt). 2004 Nov:13(9):1033-47.

6. Caceres BA, Makarem N, Hickey KT, Hughes TL. Cardiovascular disease disparities in sexual minority adults: an examination of the behavioral risk factor surveillance system (2014-2016). Am J Health Promot. 2019 May;33(4): 576-85.

7. Mojola SA, Everett B. STD and HIV risk factors among U.S. young adults: variations by gender, race, ethnicity and sexual orientation. Perspect Sex Reprod Health. 2012:44(2):125-33. https://doi.org/10.1363/4412512.

8. Boyd CJ, Veliz PT, Stephenson R, Hughes TL, McCabe SE. Severity of alcohol, tobacco, and drug use disorders among sexual minority individuals and their "not sure" Counterparts.LGBT. Health. 2019;6(1):15-22. https://doi.org/ 10.1089/lgbt.2018.0122 Epub 2019 Jan 14.

9. White Hughto JM, Pachankis JE, Willie TC, Reisner SL. Victimization and depressive symptomology in transgender adults: the mediating role of avoidant coping. J Couns Psychol. 2017;64(1):41-51.

10. Davies RD, Kessel B. Gender minority stress, depression, and anxiety in a transgender high school student. Am J Psychiatry. 2017;174(12):1151-2.

11. Veale JF, Watson RJ, Peter T, Saewyc EM. Mental health disparities among Canadian transgender youth. J Adolesc Health. 2017;60(1):44-9.

12. Nguyen KH, Trivedi AN, Shireman TI. Lesbian, gay, and bisexual adults report continued problems affording care despite coverage gains. Health Aff (Millwood). 2018;37(8):1306-12.

13. Jennings $L$, Barcelos C, McWilliams C, Malecki K. Inequities in lesbian, gay, bisexual, and transgender (LGBT) health and health care access and utilization in Wisconsin. Prev Med Rep. 2019;14:100864.

14. Conron KJ, Mimiaga MJ, Landers SJ. A population-based study of sexual orientation identity and gender differences in adult health. Am J Public Health. 2010;100(10):1953-60.

15. Valdiserri RO, Holtgrave DR, Poteat TC, Beyrer C. Unraveling health disparities among sexual and gender minorities: a commentary on the persistent impact of stigma. J Homosex. 2019;66(5):571-89.

16. Cruz TM. Assessing access to care for transgender and gender nonconforming people: a consideration of diversity in combating discrimination. Soc Sci Med. 2014:110:65-73.

17. Charlton BM, Gordon AR, Reisner SL, Sarda V, Samnaliev M, Austin SB. Sexual orientation-related disparities in employment, health insurance, healthcare access and health-related quality of life: a cohort study of US male and female adolescents and young adults. BMJ Open. 2018:8(6):e020418.

18. Goldhammer H, Maston ED, Kissock LA, Davis JA, Keuroghlian AS. National Findings from an LGBT Healthcare Organizational Needs Assessment. LGBT Health. 2018:5(8):461-8.

19. Meyer $\mathbb{H}$. Minority stress and mental health in gay men. J Health Soc Behav. 1995:36(1):38-56

20. Hendricks ML, Testa RJ. A conceptual framework for clinical work with transgender and gender nonconforming clients: an adaptation of the minority stress model. Prof Psychol Res Pract. 2012;43:460-7. 
21. Bockting WO, Miner MH, Swinburne Romine RE, Hamilton A. Coleman E stigma, mental health, and resilience in an online sample of the US transgender population. Am J Public Health. 2013;103(5):943-51.

22. Meyer $\mathrm{H}$. Prejudice, social stress, and mental health in lesbian, gay, and bisexual populations: conceptual issues and research evidence. Psychol Bull. 2003;129(5):674-97.

23. Blondeel K, Say L, Chou D, Toskin I, Khosla R, Scolaro E, Temmerman M. Evidence and knowledge gaps on the disease burden in sexual and gender minorities: a review of systematic reviews. Int J Equity Health. 2016;15:16.

24. The Lancet Public Health. LGBT: the vital fight for the right to health. Lancet Public Health. 2019;4(3):e116.

25. Buffie WC. Public health implications of same-sex marriage. Am J Public Health. 2011;101(6):986-90

26. Herdt G, Kertzner R. I do, but I can't: the impact of marriage denial on the mental health and sexual citizenship of lesbians and gay men in the United States. Sexuality Research and Social Policy. 2006;3(1):33-49.

27. Tatum AK. The interaction of same-sex marriage access with sexual minority identity on mental health and subjective wellbeing. J Homosex. 2017;64(5): 638-53.

28. Riggle ED, Rostosky SS, Horne SG. Psychological distress, well-being, and legal recognition in same-sex couple relationships. J Fam Psychol. 2010; 24(1):82-6.

29. Du Bois SN, Yoder W, Guy AA, Manser K, Ramos S. Examining associations between state-level transgender policies and transgender health. Transgend Health. 2018;3(1):220-4.

30. Gruskin S, Everhart A, Olivia DF, Baral S, Reisner SL, Kismödi E, Cruz D, Klemmer C, Reich MR, Ferguson L. "In transition: ensuring the sexual and reproductive health and rights of transgender populations." A roundtable discussion. Reprod Health Matters. 2018;26(52) 1490624.

31. Winter S, Diamond M, Green J, Karasic D, Reed T, Whittle S, Wylie K. Transgender people: health at the margins of society. Lancet. 2016; 388(10042):390-400.

32. Divan V, Cortez C, Smelyanskaya M, Keatley J. Transgender social inclusion and equality: a pivotal path to development. J Int AIDS Soc. 2016;19(3 Suppl 2):20803.

33. Reisner SL, Hughto JM, Dunham EE, et al. Legal protections in public accommodations settings: a critical public health issue for transgender and gender-nonconforming people. Milbank Q. 2015;93(3):484-515.

34. Stroumsa D. The state of transgender health care: policy, law, and medical frameworks. Am J Public Health. 2014;104(3):e31-8.

35. Paula CEA, Silva APD, Bittar CML. Legislative vulnerability of minority groups. Cien Saude Colet. 2017;22(12):3841-8.

36. Cahill SR, Makadon HJ. If they Don't count us, we Don't count: trump administration rolls Back sexual orientation and gender identity data collection. LGBT Health. 2017;4(3):171-3.

37. Gonzales G, McKay T. What an emerging trump administration means for lesbian, gay, bisexual, and transgender health. Health Equity. 2017;1(1):83-6.

38. Corrales J, Pecheny M. In: Charles J, Conaghan CM, editors. The politics of sexuality in Latin America: a reader on lesbian, Gay, Bisexual, and Transgender Rights. Pitt Latin American Series: University of Pittsburgh Press; 2010

39. Diez J. Argentina: a queer tangle between the lesbian and gay movement and the state. In Trembaly, Manon \& Paternotte, David, \& Johnson, Carol (Eds.), the lesbian and gay movement and the state: comparative insights into a transformed relationship (pp. 13-25). England: Ashgate Publishing Limited; 2011.

40. Encarnacion O. Latin America's gay rights revolution. J Democr. 2011;22(2): 105-18.

41. Paim J, Travassos C, Almeida C, Bahia L, Macinko J. The Brazilian health system: history, advances, and challenges. Lancet. 2011;377(9779):1778-97.

42. Castro MC, Massuda A, Almeida G, Menezes-Filho NA, Andrade MV, de Souza Noronha KVM, Rocha R, Macinko J, Hone T, Tasca R, Giovanella L, Malik AM, Werneck H, Fachini LA, Atun R. Brazil's unified health system: the first 30 years and prospects for the future. Lancet. 2019;394(10195):345-56.

43. Alencar Albuquerque G, de Lima GC, da Silva QG, Alves MJ, Belém JM, dos Santos Figueiredo FW, da Silva PL, Do Nascimento VB, da Silva Maciel É, Valenti VE, de Abreu LC, Adami F. access to health services by lesbian, gay, bisexual, and transgender persons: systematic literature review. BMC Int Health Hum Rights. 2016;16:2.

44. Drescher J, Schwartz A, Casoy F, McIntosh CA, Hurley B, Ashley K, Barber M, Goldenberg D, Herbert SE, Lothwell LE, Mattson MR, McAfee SG, Pula J,
Rosario V, Tompkins DA. The growing regulation of conversion therapy. J Med Regul. 2016;102(2):7-12.

45. Strickler J. Variation in Latin American LGBT rights. Master of Arts Thesis: University of Miami; 2017. Available at: http://scholarlyrepository.miami.edu/ oa_theses/690

46. Díez J. The politics of same-sex marriage in Latin America: Argentina. Chile and Mexico: Cambridge University Press; 2015.

47. Encarnación O. Out in the periphery: Latin America's gay rights revolution: Oxford University Press; 2016

48. Mahoney J. Path dependence in historical sociology. Theory Soc. 2000;29: 507-48.

49. Pierson P. Increasing Returns, Path Dependence, and the Study of Politics. Am Polit Sci Rev. 2000;94:251-67.

50. United Nations (1948) Universal Declaration of Human Rights. New York, NY, USA: United Nations. Available at: https://www.ohchr.org/EN/UDHR/ Documents/UDHR_Translations/eng.pdf Accessed in May 14, 2019.

51. International Covenant on Civil and Political Rights - ICCPR. 1966. Available at: https://www.ohchr.org/en/professionalinterest/pages/ccpr.aspx Accessed May 14, 2019.

52. International Covenant on Economic, Social and Cultural Rights - ICESCR. 1966. Available at: https://www.ohchr.org/en/professionalinterest/pages/ cescr.aspx Accessed May 14, 2019.

53. Pierson P. Not just what, but when: timing and sequence in political processes. Studies in American Political Development. 2000;14:72-92.

54. Bernier NF, Clavier C. Public health policy research: making the case for a political science approach. Health Promot Int. 2011:26:109-16.

55. Human Rights Watch. 2018. "I Have to Leave to Be Me": Discriminatory Laws against LGBT People in the Eastern Caribbean. Available at: https://www. hrw.org/report/2018/03/21/i-have-leave-be-me/discriminatory-laws-againstlgbt-people-eastern-caribbeanl.

56. Inter-American court of human rights (IACHR). Advisory opinion OC-24/17 of November 24, 2017. Series A No 24. Available at http://www.corteidh.or. cr/docs/opiniones/seriea_24_esp.pdf

57. Amnesty International. 'No safe place': Salvadorans, Guatemalans and Hondurans seeking asylum in Mexico based on their sexual orientation and or gender identity Available at: https://www.amnesty.org/download/ Documents/AMR0172582017ENGLISH.PDF

58. Office of the United Nations High Commissioner for Human Rights (OHCHR). UN Human Rights Report: 2017. Available at: http://www2. ohchr.org/english/OHCHRreport2017/allegati/Downloads/1_Whole_ Report_2017.pdf

59. Malta M, Silva AB, LeGrand S, Whetten K, Wells S. HIV/AIDS, human rights, and transgender people in Latin America. Lancet Public Health. 2019;4(6): e279.

60. Montenegro L, Velasque L, LeGrand S. Whetten K, de Mattos Russo Rafael R, Malta M. HIV Care and Prevention, Human Rights and Democracy at a Crossroad in Brazil. AIDS Behav: Public Health; 2019.

61. United Nations High Commissioner for Refugees (UNHCR). "Venezuela situation". Available at: https://www.unhcr.org/venezuela-emergency.html

62. Human Rights Watch Country Profiles: Sexual Orientation and Gender Identity, 2019. Available at: https://www.hrw.org/video-photos/interactive/2 019/02/28/sexual-orientation-gender-identity-country-profiles

63. Viteri MA \& Ocampo G. Sexual politics in Ecuador in the 2000's: a bird's eye view. Sexuality policy Watch, 2017. Available at: http://sxpolitics.org/sexualpolitics-in-ecuador-in-the-2000s-a-birds-eye-view/17140\#_ftn27

64. Wilkinson A. Sin sanidad, no hay santidad: las prácticas reparativas en Ecuador, FLACSO-Ecuador, 2013.

65. Corrales J. The politics of LGBT rights in Latin America and the Caribbean: research agendas. European Review of Latin American and Caribbean Studies. 2015;100:53-62.

66. United Nations. Living Free \& Equal: what states are doing to tackle violence and discrimination against lesbian, gay, bisexual, transgender and intersex people. United Nations: New York and Geneva; 2016. Available at: https://www.ohchr.org/Documents/Publications/LivingFreeAndEqual.pdf

\section{Publisher's Note}

Springer Nature remains neutral with regard to jurisdictional claims in published maps and institutional affiliations. 